\title{
Leaf Surface Colonization of Sugarcane by Xanthomonas albilineans and Subsequent Disease Progress Vary According to the Host Cultivar
}

Jean Heinrich Daugrois, CIRAD, UMR BGPI, Station de Roujol, 97170 Petit-Bourg, Guadeloupe, France; Rosiane Boisne-Noc, CIRAD, UMR AGAP, Station de Roujol, 97170 Petit-Bourg, Guadeloupe, France; and Philippe Rott, CIRAD, UMR BGPI, 34398 Montpellier Cedex 5, France

\begin{abstract}
Daugrois, J. H., Boisne-Noc, R., and Rott, P. 2014. Leaf surface colonization of sugarcane by Xanthomonas albilineans and subsequent disease progress vary according to the host cultivar. Plant Dis. 98:191-196.

Spread of leaf scald in modern sugarcane cultivars in Guadeloupe occurs through aerial dissemination of Xanthomonas albilineans. However, the importance of host genotype on the foliar spread of leaf scald has never been investigated. To explore this, we followed two trials used to screen sugarcane cultivars for resistance to leaf scald under natural inoculum pressure. Leaf scald epidemic characteristics were studied by measuring epiphytic populations of $X$. albilineans, leaf symptom incidence and severity, and the number of infected stalks. In both trials, epiphytic $X$. albilineans populations and incidence of foliar symptoms varied between sugarcane cultivars $(P<0.001$ in each trial for both traits) and differences in stalk infection between cultivars was

also observed $(P<0.002$ and $P<0.07$ for trials A and B, respectively) Part of the cultivar resistance that minimizes epiphytic bacterial populations is correlated to resistance to internal leaf tissue infection as expressed by leaf symptoms. No correlation was found between epiphytic $X$. albilineans populations of cultivar and the incidence of stalk infection. However, foliar symptom incidence was inconsistently correlated with stalk infection. Resistance of sugarcane to leaf scald appears to involve several traits, including limiting size of epiphytic $X$. albilineans populations and limiting the capacity of the pathogen to produce leaf necrotic symptoms by invading the leaf vascular system or to move from the leaf into the stalk.
\end{abstract}

Leaf scald, caused by Xanthomonas albilineans, is a major disease of sugarcane (a complex hybrid of Saccharum spp.) and has been reported in at least 66 countries (25). Severe yield losses due to leaf scald occurred at the beginning of the 20th century when noble canes (Saccharum officinarum) were widely grown (24). The disease was brought under control by the use of leaf-scald-resistant cultivars. However, outbreaks continued to occur periodically, especially in the Caribbean basin in the 1990s. These outbreaks were attributed to new strains of the pathogen that had the propensity to be spread aerially (13). Historically, leaf scald was known to be transmitted mechanically by cutting implements, or by planting infected cuttings from symptomless plants (25). However, unusual leaf symptoms, similar to those associated with gumming disease caused by $X$. axonopodis pv. vasculorum (29), were observed in a nursery plot in Guadeloupe in 1993 (J. H. Daugrois, unpublished data) and reported from Mauritius in 1995 (2) and from Florida in 2001 (9). In contrast to the typical pencil-line symptoms, sugarcane leaves exhibited 2- to 4-mm yellow stripes that were parallel to the veins and developed into necrotic lesions that could reach more than $25 \mathrm{~cm}$ in length (10). These unusual symptoms, from which $X$. albilineans was isolated, were attributed to aerial transmission of the pathogen $(9,11)$.

Colonization of the plant canopy by Xanthomonas spp. is known to occur after short-distance dissemination of bacteria via water splashing or canopy fauna $(15,17,20,23)$, or due to long-distance dissemination via tropical storms and hurricanes $(8,11,16,23)$. Similar to other xanthomonads $(6,22,30)$, epiphytic survival of $X$. albilineans is expected to be promoted by high relative humidity, rainfall, and mild to warm temperatures that occur in lowland areas of tropical countries. Rain favors colonization of the sugarcane

Corresponding author: J. H. Daugrois,

E-mail: jean-heinrich.daugrois@cirad.fr

Accepted for publication 7 July 2013.

http://dx.doi.org/10.1094/PDIS-02-13-0195-RE

(C) 2014 The American Phytopathological Society leaves by $X$. albilineans in Guadeloupe (8). Necrotic lesions associated with leaf scald can appear within 3 to 7 weeks after detection of the pathogen on leaf surfaces, suggesting that invasion of internal leaf tissues occurs after phyllosphere colonization $(8,11)$. Additionally, stalk infection of susceptible 'B69566' was shown to be more dependent on weather conditions than contamination between canes by cutting implements (8). Phyllosphere contamination seems to be important in leaf scald epidemics in humid tropical areas such as Guadeloupe (10).

Resistance of sugarcane to leaf scald varies according to the sugarcane cultivar (28). Comstock (9) observed variation in the number of leaf lesions between sugarcane cultivars after exposure of the plants to aerial inoculum. The two most susceptible sugarcane cultivars showed the highest number of necrotic symptoms but only a few stalks showed systemic infection. Additionally, no correlation was found between incidence or severity of foliar symptoms and incidence of systemically infected stalks (9). Even though correlations between $X$. albilineans epiphytic populations and foliar symptoms and subsequent stalk colonization were found with susceptible B69566 $(8,10)$, no data are available regarding the effect of cultivar on leaf surface colonization by the pathogen and subsequent disease symptoms. Therefore, the objective of this study was to analyze the relationship between sugarcane cultivars and phyllosphere contamination by $X$. albilineans and subsequent leaf symptom development and sugarcane stalk infection.

\section{Materials and Methods}

Plant material. Twenty-three cultivars from the final stage of selection of the local breeding program were used (Table 1). These cultivars were tested in two separate trials (A and B, planted in June 2005 and June 2008, respectively) that contained 8 and 15 cultivars, respectively. Additionally, each trial included B69566, which is susceptible to leaf scald, and 'B8008', which is resistant to the disease (28). The two trials were set up separately using a completely randomized block design with three replications. Cultivars were planted as cuttings in 6-by-6-m plots (four rows of $6 \mathrm{~m}$ ) with 100 three-bud cuttings per plot. The cuttings originated from breeding nurseries established with hot-water-treated cuttings $(2.5$ $\mathrm{h}$ at $50^{\circ} \mathrm{C}$ ). Plants were grown according to local commercial prac- 
tices (http://www.ctcs-martinique.org/?q=pages/ctcs-martinique/5culture). Sugarcane was harvested in the plant cane (PC) crop in June 2006 (trial A) and June 2009 (trial B). Leaf surface populations of $X$. albilineans, symptoms, and stalk infection were assessed during PC and the first ratoon (R1) crops and the following foliar characteristics were recorded for each cultivar: leaf width (large $=>5 \mathrm{~cm}$, medium $=3$ to $5 \mathrm{~cm}$, and thin $=<3 \mathrm{~cm}$ ) and leaf aspect (erect, medium drooping and drooping) (Table 1). To minimize the effect of cross contamination between plots, only the two middle rows of each plot were assessed.

Populations of $X$. albilineans on the sugarcane leaf surface. Epiphytic populations of $X$. albilineans were determined by sampling water droplets on different leaves from at least 20 plants early in the morning (7:00 to 9:00 A.M.) along the two middle rows of each sugarcane plot. Water was sampled on the four first fully developed leaves from the top. Sampling was performed at least twice per crop year during the second half of the wet season (September to November) for each trial. Forty water droplets were sampled per plot with a 1-ml micropipette, with new sterile micropipette tips used between plots. Water droplets from each plot were pooled ( 1 to $1.5 \mathrm{ml}$ of total volume) in a $2-\mathrm{ml}$ sterile microtube and then transferred to the laboratory for enumeration of $X$. albilineans populations, as previously described (8). Undiluted and 100-fold dilutions of each sample were plated on $X$. albilineans selective medium (XAS) with a Spiral system (Interscience). XAS medium is Wilbrink's medium amended with $\mathrm{KBr}$, fungicides, and antibiotics (12). Epiphytic populations of the pathogen were expressed as $\mathrm{CFU} / \mathrm{ml}$.

Assessment of foliar leaf scald disease symptoms. Foliar symptom severity or disease index (DI) and foliar symptom incidence (FSIc) following the aerial spread of $X$. albilineans were assessed in PC and R1 crops at the end of the wet season. Twenty arbitrarily selected sugarcane stalks from the two middle rows of each plot were assessed individually based on symptoms observed on all leaves and scored using a symptom severity scale ranging from 0 to 4 . This scale was adapted from the one described previ- ously (8) with $0=$ no symptoms, $1=$ one small necrotic lesion $(<15$ $\mathrm{cm}$ in length) on one leaf, $2=$ small necrotic lesions on more than one leaf, $3=$ necrotic lesions up to $25 \mathrm{~cm}$ in length, and $4=$ necrotic lesions $>25 \mathrm{~cm}$ in length. Data were computed as DI per plot where DI $=100 \times(\Sigma$ score $/ 4 \times N)$, with $N$ being the number of sugarcane stalks observed $(N=20)$. We also computed the proportion of these stalks showing foliar necrotic lesions as incidence of stalks with foliar symptoms (FSIc).

Systemic colonization of sugarcane stalks. At the end of each crop year (PC and R1) and for each trial, 30 sugarcane stalks were arbitrarily sampled from the two middle rows of each plot, with the exception of the R1 crop of trial A. This crop was unexpectedly damaged before the planned stalk sampling date. Systemic infection of each stalk was assessed by isolating the pathogen from two different stalk locations, as previously described (8). The lower location corresponded to the three to four internodes at the base of the sugarcane stalk and the upper location corresponded to the three to four last internodes near the top of the stalk. Imprints of cut sections of each stalk location were performed by the stalk blot inoculation technique with XAS medium, as previously described (7). X. albilineans recovery was recorded after 5 days of incubation at $28^{\circ} \mathrm{C}$. Identity of colonies was determined by serology (26). Sugarcane stalks that were colonized in either the upper or lower parts were considered as colonized and were expressed as the percentage of $X$. albilineans infected stalks (XaIS).

Statistical analyses. Statistical analyses were performed with SAS 9.3 software (SAS Institute Inc.). Correlation between leaf surface populations of $X$. albilineans and subsequent disease severity (DI) was tested by Pearson's coefficient measurement on a plot basis. Spatial autocorrelation of leaf surface populations of $X$. albilineans was tested with Moran's statistics using the autocorrelation analysis features of the VARIOGRAM procedure of SAS software. Closest-neighbor plots were considered in the program for spatial autocorrelation analyses. Prior to comparison analyses, data were subjected to transformation for normalization. Epiphytic populations of $X$. albilineans were log transformed, whereas FSIc

Table 1. Origin and architectural traits of the tested cultivars in trials $\mathrm{A}$ and $\mathrm{B}^{\mathrm{a}}$

\begin{tabular}{|c|c|c|c|c|c|c|}
\hline Cultivar & Location of breeding/first selection ${ }^{b}$ & Area recommended $^{c}$ & Leaf width ${ }^{d}$ & Leaf aspect $\mathrm{t}^{\mathrm{e}}$ & Tillering $^{\mathrm{f}}$ & Field tria \\
\hline B85792 & Barbados & GT & $\mathrm{L}$ & ED & M & B \\
\hline B86221 & Barbados & BT & $\mathrm{T}$ & ED & $\mathrm{H}$ & B \\
\hline B881104 & Barbados & BT & M & ED & M & $\mathrm{B}$ \\
\hline B88804 & Barbados & BT & $\mathrm{L}$ & ED & $\mathrm{M}$ & A \\
\hline B89452 & Barbados & GT & $\mathrm{L}$ & $\mathrm{D}$ & $\mathrm{M}$ & $\mathrm{B}$ \\
\hline B91948 & Barbados & BT & M & $\mathrm{D}$ & M & A \\
\hline BT 87220 & Barbados/Trinidad & GT & $\mathrm{M}$ & $\mathrm{D}$ & M & B \\
\hline ВТ83339 & Barbados/Trinidad & BT & $\mathrm{L}$ & $\mathrm{D}$ & M & A \\
\hline DB8684 & Barbados/Guyana & BT & M & ED & $\mathrm{L}$ & B \\
\hline KNB91102 & Barbados/Soudan & BT and GT & $\mathrm{M}$ & ED & M & B \\
\hline FR87166 & Guadeloupe & GT & $\mathrm{L}$ & $\mathrm{D}$ & $\mathrm{M}$ & A \\
\hline FR88196 & Guadeloupe & GT & $\mathrm{T}$ & E & M & B \\
\hline FR89423 & Guadeloupe & GT & M & ED & M & B \\
\hline FR89746 & Guadeloupe & GT & $\mathrm{M}$ & ED & $\mathrm{H}$ & B \\
\hline FR90881 & Guadeloupe & BT & $\mathrm{M}$ & $\mathrm{D}$ & $\mathrm{H}$ & B \\
\hline FR91384 & Guadeloupe & BT & $\mathrm{M}$ & D & $\mathrm{H}$ & B \\
\hline FR92394 & Guadeloupe & BT & $\mathrm{M}$ & ED & $\mathrm{H}$ & $\mathrm{B}$ \\
\hline FR94129 & Guadeloupe & BT & $\mathrm{M}$ & $\mathrm{E}$ & M & A \\
\hline FR94218 & Guadeloupe & BT & M & ED & M & $\mathrm{A}$ \\
\hline FR94295 & Guadeloupe & BT & $\mathrm{L}$ & $\mathrm{D}$ & M & B \\
\hline FR95285 & Guadeloupe & GT & $\mathrm{L}$ & E & M & A \\
\hline FR95579 & Guadeloupe & GT & M & ED & M & B \\
\hline FR96018 & Guadeloupe & GT & M & D & M & A \\
\hline B69566" & Barbados & BT & $\mathrm{L}$ & $\mathrm{D}$ & M & $\mathrm{AB}$ \\
\hline B $8008^{\mathrm{h}}$ & Barbados & BT & $\mathrm{T}$ & ED & M & $\mathrm{AB}$ \\
\hline
\end{tabular}

a All cultivars have good sucrose content and were considered as promising cultivars by the local breeding program.

${ }^{\mathrm{b}}$ Only one geographical location means that breeding and selection occurred in the same location.

${ }^{\mathrm{c}} \mathrm{BT}=$ Basse Terre, high-humidity area with ferralitic soils, and GT $=$ Grande Terre, relatively dry area with clay soils.

${ }^{\mathrm{d}} \mathrm{L}=$ large, $>5 \mathrm{~cm} ; \mathrm{M}=$ medium, 3 to $5 \mathrm{~cm}$; and $\mathrm{T}=$ thin, $<3 \mathrm{~cm}$.

${ }^{\mathrm{e}} \mathrm{E}=$ erect, $\mathrm{ED}=$ erect and drooping at third top part of the leaf, and $\mathrm{D}=$ drooping.

${ }^{f}$ Tillering: $\mathrm{H}>100,000$ stalks/ha, 70,000 $<\mathrm{M}<100,000$ stalks/ha, and $\mathrm{L}<70,000$ stalks/ha.

${ }^{g}$ Susceptible control.

${ }^{\text {h }}$ Resistant control. 
and XaIS were transformed with $\arcsin$ function $[y=\operatorname{arsin} \sqrt{ }(n / t)]$, with $n$ being the number of diseased stalks and $t$ the total number of observed stalks. Cultivar effects on disease $(y)$ were analyzed with the GLM procedure for each crop year and with crop year (CP and $\mathrm{R} 1$ ) as repeated measure with the model $y \mathrm{PC} y \mathrm{R} 1=$ cultivar. Crop year data means were obtained with Lsmeans statement under the GLM procedure. Cultivar means were compared by a $t$ test of the means with the Lsmeans statement under the GLM procedure for each crop year. DI data were not used for analysis of variance because they are based on ordinal data. Cultivar means were used for testing the correlation (Pearson's correlation coefficient R) between data series and the probability for a greater $\mathrm{R}$ under the null hypothesis of no correlation.

\section{Results}

Because the objective of this study was to investigate the impact of sugarcane cultivars on epiphytic populations of $X$. albilineans and subsequent appearance of leaf symptoms, data sets were selected based on the correlation observed between severity of symptoms (DI) and previous leaf surface populations of $X$. albilineans on a plot basis. Best fits were observed when pathogen populations were measured 4 to 6 weeks before symptom assessments (Table 2). These data sets corresponded to well-established epiphytic populations of $X$. albilineans on control plants, as illustrated by the size of pathogen populations for the crop years 2005, 2006, 2008, and 2009 (7.0, 6.7, 6.2, and $7.3 \log \mathrm{CFU} / \mathrm{ml}$ of water, respectively) and the relative low variation observed (standard deviations of 0.2 , $0.1,0.8$, and 0.2 , respectively). However, the small variation observed between crop years is correlated with rainfall that preceded sampling with $P$ values of $0.0096,0.0016$, and 0.087 for 1,2 , and 3 months of rainfall, respectively. As an example, the 2-month cumulative rainfall corresponded to $611,490,315$, and $752 \mathrm{~mm}$ of rain for crop years 2005, 2006, 2008, and 2009, respectively. The data sets used for measuring cultivar effects on pathogen populations corresponded to week 41 for the PC crop of trials A and PC and R1 crops for trial B, and week 46 for the R1 crop of trial A (Table 2, indicated in bold). No spatial autocorrelation was observed for these data series. However, spatial autocorrelation was significant in the PC crop of trial A at week 39, when several plants at one edge of the trial remained noninfected, and in the R1crop of trial B at week 38 because of a block that had higher pathogen populations than the other blocks.

Leaf surface populations of $X$. albilineans. Pathogen populations on sugarcane leaf surfaces varied between cultivars in PC and R1 crops. In trial A, two sugarcane cultivars ('FR95285' and 'FR94129') consistently exhibited the lowest leaf surface populations in both crop years $\left(3.5 \times 10^{5}\right.$ and $12.9 \times 10^{5} \mathrm{CFU} / \mathrm{ml}$ for FR95285 and $5.5 \times 10^{5}$ and $3.6 \times 10^{5} \mathrm{CFU} / \mathrm{ml}$ for FR94129), whereas 'FR96018' exhibited the highest $\left(1.2 \times 10^{7}\right.$ and $1.3 \times 10^{7}$ $\mathrm{CFU} / \mathrm{ml}$ ) (Fig. 1). In trial B, the two sugarcane cultivars showing the lowest leaf surface populations in PC crop also had the lowest leaf surface populations in R1 crop $\left(72.1\right.$ and $5.1 \times 10^{5} \mathrm{CFU} / \mathrm{ml}$ for 'B89452' and 24.5 and $8.4 \times 10^{5} \mathrm{CFU} / \mathrm{ml}$ for 'FR88196'). On the other hand, 'FR95579' exhibited the highest populations $\left(2.0 \times 10^{6}\right.$ and $2.2 \times 10^{7} \mathrm{CFU} / \mathrm{ml}$ ) (Fig. 2). In both trials, mean epiphytic populations of $X$. albilineans on control cultivars B69566 (susceptible) and B8008 (resistant) were high and similar (1.7 to $20.5 \times 10^{6}$ $\mathrm{CFU} / \mathrm{ml}$ ) (Figs. 1 and 2). The effect of the sugarcane cultivar on leaf surface populations of $X$. albilineans was significant $(P<$ 0.0001 and $P=0.001$ in trials $\mathrm{A}$ and $\mathrm{B}$, respectively), whereas the effect of crop year was significant only in trial B $(P<0.0001)$, where epiphytic populations were higher in the R1 crop. Cultivarcrop year interaction was never significant, indicating a reliable effect of the sugarcane cultivar on leaf surface populations of $X$. albilineans across crop years despite variation in rainy conditions.

A 20- to 10,000-fold increase in epiphytic populations of X. albilineans was observed between the least and the most colonized cultivars (Figs. 1 and 2) depending on the crop year. Compared with control plants, at least two groups of cultivars with different epiphytic populations were distinguishable in each trial. Three cultivars in trial A (FR94129, FR95285, and 'R87166') and four cultivars in trial B (B89452, 'DB8684', FR88196, and 'FR89423') had, in both crop cycles, epiphytic $X$. albilineans populations that were lower than the populations observed in at least one of the two control cultivars (B69566 and B8008; $P=0.0003$ to 0.09). In trials $\mathrm{A}$ and $\mathrm{B}$, the resistant and susceptible control cultivars belonged to the group that supported the highest $X$. albilineans epiphytic populations, despite their differences in resistance to systemic infection. Three cultivars in trial A ('B88804', 'B91948', and FR96018) and five cultivars in trial B ('B85792', 'B881104', 'FR94295', FR95579, and 'KnB91102') consistently showed no differences in epiphytic populations of $X$. albilineans compared with the controls $(P>0.10)$.

Leaf architecture was not a key factor in the establishment of epiphytic populations of the pathogen because cultivars with large drooping leaves belonged to the two groups (B69566, FR96018, and FR94295 versus 'FR87166' and B89452). Similarly, leaf width did not impact epiphytic populations because control B8008 had thin leaves. However, of the 25 analyzed cultivars, the 3 (FR94129, FR95285, and FR88196) with erect leaves belonged to the group of cultivars with the lowest epiphytic populations of $X$. albilineans but all 3 exhibited foliar symptoms.

Foliar symptoms. Because DI and FSIc were closely related (with Pearson's correlation coefficient values between both parameters of 0.93 and 0.97 for trials $A$ and $B$, respectively), we used incidence data (FSIc) for all statistical comparisons. The effect of the sugarcane cultivar on FSIc was significant $(P<0.0001$ for trials $\mathrm{A}$ and $\mathrm{B}$ ) but the effect of crop year was only significant in trial B $(P=0.015)$. No significant cultivar-crop year interaction was observed. In trial A (Fig. 1), FSIc ranged from 0\% ('BT83339' in PC and R1 crops) to 99 to $100 \%$ (FR96018 in PC and R1 crops). In trial B (Fig. 2), FSIc ranged from 0\% ('B86221' in PC and R1 crops) to $95 \%$ (B69566 in the PC crop). For susceptible B69566, FSIc was 93, 68, 95, and 70\% in PC and R1 crops of trial A and B, respectively. Symptom development following aerial infection of controls B8008 and B69566, analyzed by FSIc, was different $(P=$ 0.0004 ) with data sets from both trials. Additionally, consistency of each response of these cultivars was illustrated by the absence of significant crop year effect and crop-year-cultivar interaction effect in each trial, and the absence of significant trial and trial-cultivar interaction effects. Therefore, the response of the other cultivars to aerial spread of $X$. albilineans was compared with that of

Table 2. Correlation between size of epiphytic populations of Xanthomonas albilineans and severity of foliar symptoms ${ }^{\mathrm{a}}$

\begin{tabular}{lccccccccc}
\hline & \multicolumn{7}{c}{ Assessment of $\boldsymbol{X}$. albilineans populations at week } \\
\cline { 3 - 9 } Trial-crop & Symptoms at week $^{\mathbf{b}}$ & $\mathbf{3 3}$ & $\mathbf{3 6}$ & $\mathbf{3 7}$ & $\mathbf{3 8}$ & $\mathbf{3 9}$ & $\mathbf{4 1}$ & $\mathbf{4 5}$ & $\mathbf{4 6}$ \\
\hline A-PC & 45 & $0.37^{*}$ & $\ldots$ & $0.39^{*}$ & $\ldots$ & $0.44^{* *}$ & $\mathbf{0 . 5 7 * * *}$ & $0.40^{*}$ & $\ldots$ \\
A-R1 & 50 & $\ldots$ & $0.47^{* *}$ & $\ldots$ & $\ldots$ & $\ldots$ & $\ldots$ & $\ldots$ \\
B-PC & 47 & $\ldots$ & $\ldots$ & $\ldots$ & $\ldots$ & $\ldots$ & $\mathbf{0 . 3 5 * *}$ & $0.15 \mathrm{~ns}$ & $\ldots$ \\
B-R1 & 45 & $\ldots$ & $\ldots$ & $\ldots$ & $0.14 \mathrm{~ns}$ & $\ldots$ & $\mathbf{0 . 2 3} *$ & $\ldots$ & $\ldots$ \\
\hline
\end{tabular}

a Pearson's correlation coefficient was calculated between data obtained on plot basis in trials A and B in plant cane (PC) and first ratoon (R1) crops. Weeks indicate the week of the sampling year (date). Probability of retained Ho (no correlation): ***, **, and * indicate $P \leq 0.001,0.010$, and 0.100 , respectively; $\mathrm{ns}=$ nonsignificant. Data in bold were used to measure cultivar effects on pathogen populations.

b Assessment of symptoms at given week. 
control plants. In trial A, FSIc of six of eight cultivars was lower $(P$ $<0.05)$ than FSIc of susceptible B69566 in both crop cycles, and FSIc of FR96018 was either similar or higher than FSIc of B69566 according to crop year. In trial B, 12 of the 15 cultivars had a lower $(P<0.05)$ FSIc value than B69566 in both crop years, and FR95579 had the highest FSIc. In contrast, FSIc values for 'FR92394' and FR94295 were lower than values for susceptible B69566 in the PC crop $(P<0.0001)$ but not the R1 crop $(P=0.12$ and 0.24 respectively).

Stalk infection by $X$. albilineans. The percentages of stalks of B69566 infected by $X$. albilineans in the PC crop of trial A and PC and R1 crops of trial B were 29,21 , and $20 \%$, respectively, suggesting that disease pressure was higher in trial A. XaIS varied according to cultivar in trial A $(P=0.002)$; however, cultivar effect was almost significant $(P=0.07)$ in trial $\mathrm{B}$ when both crop years were considered. Because of missing data for trial A, variation of the proportion of infected samples according to the crop year could

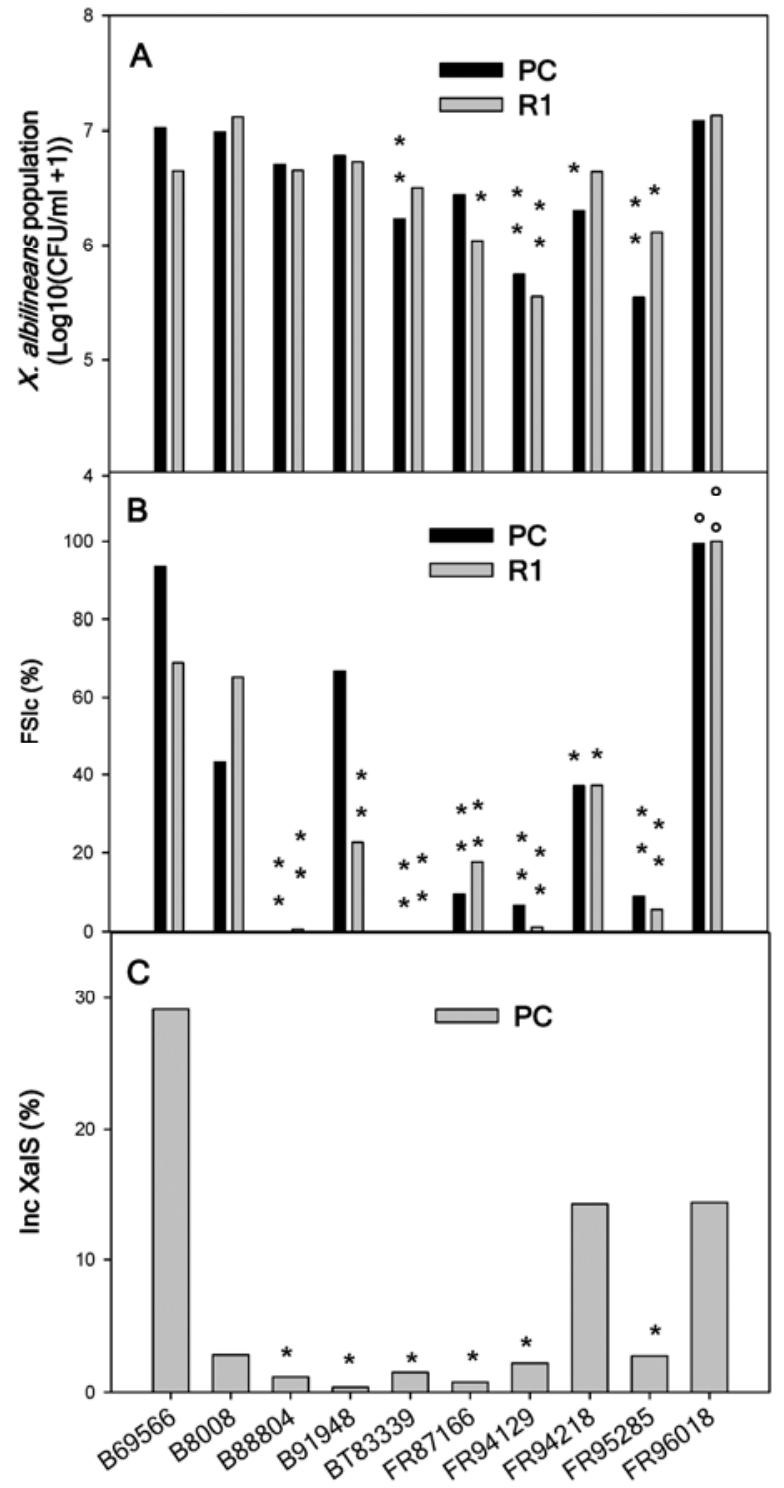

Fig. 1. Leaf scald data of trial A. A, Xanthomonas albilineans leaf surface populations measured at week 41 in plant cane (PC) crop and week 47 in first ratoon (R1) crop. B, Incidence of canes with foliar symptoms (FSIc) measured at week 45 in PC crop and week 50 in R1 crop. C, Incidence of canes with $X$. albilineans-infected stalks (Inc XalS) at the end of the PC crop. Values are the estimated means of the transformed data, obtained under SAS GLM procedure. Cultivars were compared with 'B69566' (susceptible) and 'B8008' (resistant) control cultivars. Symbols: ${ }^{*}$ indicates that the cultivar value is lower than the value of one $\left(^{*}\right)$ or both $\left(^{* *}\right)$ controls and ${ }^{\circ}$ indicates that the cultivar value is higher than the value of one $\left({ }^{\circ}\right)$ or both $\left({ }^{\circ}\right)$ controls, at $P<0.05$. only be determined for trial B. The effect of crop year on stalk infection was significant $(P=0.002)$ but there was no interaction between crop year and cultivar. Based on the percentage of infected stalks, two cultivars in trial A ('FR94218' and FR96018) were not different from B69566. Other cultivars and the resistant control showed a lower percentage of stalk infection than B69566 ( $P$ of 0.0002 to 0.003 ; Fig 1 ). In trial B, five cultivars ('BT87220', FR89423, FR92394, FR94295, and FR95579) consistently showed a lower percentage of stalk infection than B69566 in both crops $(P$ $<0.05$; Fig 2). However, the resistant control B8008 that had 6 and $5 \%$ of infected stalks in PC and R1, respectively, was not statistically different from the susceptible control B69566 $(P=0.08$ and $0.15)$.

Relationship between epiphytic populations of $X$. albilineans and FSIc. In PC of the two trials, a significant correlation was found between epiphytic pathogen population and FSIc, with R of 0.71 and 0.57 for trials A and B, respectively (Tables 3 and 4). In



Fig. 2. Leaf scald data of trial B. A, Xanthomonas albilineans leaf surface populations measured at week 41 in plant cane (PC) and first ratoon (R1) crops. B, Incidence of canes with foliar symptoms (FSIc) measured at week 47 in PC crop and week 45 in R1 crop. C, Incidence of canes with $X$. albilineans-infected stalks (Inc XalS) at the end of the PC and R1 crops. Values are the estimated means of the transformed data, obtained under SAS GLM procedure. Cultivars were compared with 'B69566' (susceptible) and 'B8008' (resistant) control cultivars. Symbols: * indicates that the cultivar value is lower than the value of one $\left({ }^{*}\right)$ or both $\left.{ }^{* *}\right)$ controls and ${ }^{\circ}$ indicates that the cultivar value is higher than the value of one $\left({ }^{\circ}\right)$ or both $\left({ }^{\circ}\right)$ controls, at $P<0.05$. 
$\mathrm{R} 1$, a similar correlation was found in trial $\mathrm{A}(\mathrm{R}=0.70)$ but not in trial $\mathrm{B}(\mathrm{R}=0.33)$, in which mean populations were higher because of higher rainfall and less epiphytic population variation between cultivars.

Relationship between stalk infection and other traits. In both trials, the percentage of infected stalks was not correlated with epiphytic populations of $X$. albilineans (Tables 3 and 4). In contrast, incidence of foliar symptoms and percentage of infected stalks were correlated in the PC crop of trial A. However, this correlation was not significant in trial B (Tables 3 and 4).

\section{Discussion}

Each of the 25 sugarcane cultivars tested in this study experienced at least two leaf scald epidemics. Results from the two crop years were consistent because no significant crop-year-cultivar interaction was observed for any of the leaf scald resistance traits studied.

A 30- to 70-fold variation of epiphytic X. albilineans population was observed between cultivars when populations of $X$. albilineans were well established in the trials with mean epiphytic populations of 6.5, 6.5, and $6.6 \log \mathrm{CFU} / \mathrm{ml}$ for PC of trial A and R1 of trial A and $\mathrm{B}$, respectively, due to rainy conditions. When conditions were less favorable for development of epiphytic populations and spread of the pathogen, variation level between cultivars increased up to $10^{5}$-fold as observed for PC of trial B that experienced the lowest amount of rain, with $X$. albilineans mean populations of $4.4 \mathrm{log}$ $\mathrm{CFU} / \mathrm{ml}$. The consistent relative variation of bacterial populations between sugarcane cultivars indicated that the genotype can modulate the size of epiphytic populations of $X$. albilineans despite the variation between crop years that can be influenced by climate conditions.

If plant architecture such as erect leaves may limit epiphytic populations of $X$. albilineans, other characteristics may also play a role because cultivars with non-erect leaves also had low surface populations of the pathogen. Foliar phytobacteria are considered to form a continuum between the inner and outer space of the leaf, which is regulated by natural openings such as stomata (4). Therefore, we postulate that some sugarcane cultivars may modulate this continuum, (18) by unknown mechanisms that need further study.

Variation in incidence of foliar symptoms that might reflect the population of $X$. albilineans within leaf tissues was only partially related to epiphytic populations of the pathogen. However, as expected, foliar symptoms varied greatly between sugarcane cultivars and high epiphytic populations of $X$. albilineans appeared to be associated with but not consistently linked to symptom appearance.
This is illustrated by two sugarcane cultivars in trial A and five cultivars in trial B that had high epiphytic populations of $X$. albilineans but showed no or very few foliar symptoms. This suggested that different resistance mechanisms might be involved in limiting bacterial multiplication on and in the leaf.

To produce foliar symptoms, bacteria need to invade and colonize the leaf and, because $X$. albilineans is a xylem-invading pathogen, they must reach the vascular system. Within the leaf, the pathogen will face host defense mechanisms that may be triggered by bacterial lipopolysaccharides (outer membrane glycolipids of gram-negative bacteria; 14). Plant defense response can be suppressed by extracellular polysaccharides (EPS) produced by the pathogen (1) but EPS can also trigger plant defense responses according to host genotype. This phenomenon was described for Ralstonia solanacearum on resistant and susceptible tomato cultivars (19). These molecules remain to be characterized in X. albilineans, which produces surface polysaccharides that may be virulence factors (27). X. albilineans may also migrate in the leaf without producing symptoms because it can be recovered up to 30 $\mathrm{cm}$ above and below necrotic lesions (9).

Inconsistent relationships were found between epiphytic populations of $X$. albilineans, sugarcane leaf symptoms, and stalk infection. Although the cultivars exhibiting the highest incidence of stalk infection also showed the highest epiphytic populations of $X$. albilineans, one of the three cultivars with the highest incidence of stalk infection in trial B ('FR90881') showed few leaf symptoms. Inversely, several cultivars, including the resistant control B8008, showed a relatively high FSIc but a low level of stalk infection. Therefore, resistance to $X$. albilineans may vary between leaves and stalks, and different resistance mechanisms may be involved. A similar phenomenon was observed with cassava genotypes tested for resistance to cassava blight (31). Leaf blight due to colonization of the leaf by $X$. axonopodis pv. manihotis was not related to wilt due to stem infection, and different resistance mechanisms were hypothesized in cassava stems and leaves. Xylella fastidiosa, another xylem-invading pathogen closely related to $X$. albilineans (21), also showed differences in capacity to colonize different organs of grape plants according to the host genotype (3). Limited multiplication of Xylella fastidiosa was observed in the stem of grape cultivars resistant to Pierce's disease, whereas populations of the pathogen were similar in the petiole of susceptible and resistant cultivars.

In this study, we produced evidence of a lack of correlation between the different measurable ways in which the pathogen interacts with the host that suggests that complexity exists in the re-

Table 3. Pearson's correlation coefficient between means of cultivar resistant traits of trial A in PC (plant cane) and R1 (first ratoon) crops ${ }^{\mathrm{a}}$

\begin{tabular}{lccccc}
\hline Trait & Xapop PC & Xapop R1 & FSIc PC & FSIc R1 & XaSI PC \\
\hline Xapop PC & $\ldots$ & $0.81927,0.0037^{* *}$ & $0.70859,0.0218^{*}$ & $\ldots$ & $0.39475,0.2589$ \\
Xapop R1 & $0.81927,0.0037^{* *}$ & $\ldots$ & $\ldots$ & $0.70085,0.0240^{* *}$ & \\
FSIc PC & $0.70859,0.0218^{*}$ & $\ldots$ & $\ldots$ & $0.88190,0.0007 * *$ & $0.71544,0.0200^{*}$ \\
FSIc R1 & $\ldots$ & $0.70085,0.0240^{* *}$ & $0.88190,0.0007^{* *}$ & $\ldots$ & $\ldots$ \\
XaIS PC & $0.39475,0.2589$ & $\ldots$ & $0.71544,0.0200^{* *}$ & $\ldots$ & $\ldots$ \\
\hline
\end{tabular}

${ }^{a}$ Xapop $=$ epiphytic populations of $X$. albilineans, FSIc $=$ foliar symptoms incidence, and XaSI = proportion of $X$. albilineans infected stalks. Probability of a greater R under null hypothesis of no correlation is indicated in italics; * and ** indicate significance at Bonferroni threshold $(P / n)$ for $P=0.10$ and 0.05 , respectively, with $n=$ number of correlations treated by trait.

Table 4. Pearson's correlation coefficient between means of cultivar resistant traits of trial B in PC (plant cane) and R1(first ratoon) crops ${ }^{\mathrm{a}}$

\begin{tabular}{|c|c|c|c|c|c|c|}
\hline Trait & Харор PC & Xapop R1 & FSIc PC & FSIc R1 & XaIS PC & XaIS R1 \\
\hline Xapop PC & & $0.53481,0.0270^{*}$ & $0.57068,0.0167 * *$ & & $0.22426,0.3869$ & \\
\hline Xарор R1 & $0.53481,0.0270^{*}$ & $\ldots$ & $\ldots$ & $0.33185,0.1932$ & & $0.26285,0.3081$ \\
\hline FSIc PC & $0.57068,0.0167 * *$ & 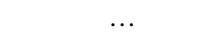 & $\ldots$ & $0.84427,<0.0001 * *$ & $0.32045,0.2098$ & \\
\hline FSIc R1 & & $0.33185,0.1932$ & $0.84427,<0.0001 * *$ & $\ldots$ & $\ldots$ & $0.35322,0.1643$ \\
\hline XaIS PC & $0.22426,0.3869$ & & $0.32045,0.2098$ & & & $0.64326,0.0053 * *$ \\
\hline XaIS R1 & $\ldots$ & $0.26285,0.3081$ & $\ldots$ & $0.35322,0.1643$ & $0.64326,0.0053 * *$ & $\ldots$ \\
\hline
\end{tabular}

${ }^{a}$ Xapop $=$ epiphytic populations of $X$. albilineans, FSIc $=$ foliar symptoms incidence, and XaSI $=$ proportion of $X$. albilineans infected stalks. Probability of a greater R under null hypothesis of no correlation is indicated in italics; * and ** indicate significance at Bonferroni threshold $(P / n)$ for $P=0.10$ and 0.05 , respectively, with $n=$ number of correlations treated by trait. 
sistance response in the host that may differ according to the plant organ studied. In tropical areas such as Guadeloupe, the epiphytic phase of the pathogen seems to be important in the disease cycle of leaf scald (10). Resistance minimizing leaf infection will benefit the plant by limiting new infections and epidemic events, especially when the main disease impact on sugarcane arises following xylem blockage and diffusion of metabolic wastes due to high $X$. albilineans populations in invaded stalk xylem elements (5). Regarding the epiphytic phase as the main inoculation process, identification of genetic factors regulating the variation of epiphytic populations and leaf infections observed herein will be an important step for disease management through plant breeding.

\section{Acknowledgments}

This work was supported by the European Regional Development Fund (ERDF) and the Regional Council of Guadeloupe. We thank the staff of CIRAD's sugarcane experiment station at Roujol in Guadeloupe for providing and planting sugarcane material; N. Adjanoh-Lubin, S. Joseph from CIRAD, and J. Zhao from Yunnan Sugarcane Research Institute for their contribution in determination of $X$. albilineans epiphytic populations and stalk infection; C. Kaye for critical reading of the manuscript; and anonymous reviewers for useful suggestions to improve the manuscript.

\section{Literature Cited}

1. Aslam, S. N., Newman, M. A., Erbs, G., Morrissey, K. L., Chinchilla, D., Boller, T., Jensen, T. T., De Castro, C., Ierano, T., Molinaro, A., Jackson, R. W., Knight, M. R., and Cooper, R. M. 2008. Bacterial polysaccharides suppress induced innate immunity by calcium chelation. Curr. Biol. 18:10781083.

2. Autrey, L. J. C., Saumtally, S., Dookun, A., Sullivan, S., and Dhayan, S. 1995. Aerial transmission of the leaf scald pathogen, Xanthomonas albilineans. Proc. Int. Soc. Sugar Cane Technol. 21:508-526.

3. Baccari, C., and Lindow, S. E. 2011. Assessment of the process of movement of Xylella fastidiosa within susceptible and resistant grape cultivars. Phytopathology 101:77-84.

4. Beattie, G. A., and Lindow, S. E. 1995. The secret life of foliar bacterial pathogens on leaves. Annu. Rev. Phytopathol. 33:145-172.

5. Birch, R. G. 2001. Xanthomonas albilineans and the antipathogenesis approach to disease control. Mol. Plant Pathol. 2:1-11.

6. Bock, C. H., Parker, P. E., and Gottwald, T. R. 2005. Effect of simulated wind-driven rain on duration and distance of dispersal of Xanthomonas axonopodis pv. citri from canker-infected citrus trees. Plant Dis. 89:71-80.

7. Champoiseau, P., Daugrois, J. H., Pieretti, I., Cociancich, S., Royer, M., and Rott, P. 2006. High variation in pathogenicity of genetically closely related strains of Xanthomonas albilineans, the sugarcane leaf scald pathogen, in Guadeloupe. Phytopathology 96:1081-1091.

8. Champoiseau, P., Rott, P., and Daugrois, J. H. 2009. Epiphytic populations of Xanthomonas albilineans and subsequent sugarcane stalk infection are linked to rainfall in Guadeloupe. Plant Dis. 93:339-346.

9. Comstock, J. C. 2001. Foliar symptoms of sugarcane leaf scald. Sugar J. 64:23-32.

10. Daugrois, J. H., Boisne-Noc, R., Champoiseau, P., and Rott, P. 2012. The revisited infection cycle of Xanthomonas albilineans, the causal agent of leaf scald of sugarcane. Funct. Plant Sci. Biotechnol. 6 (Spec. Issue 2):91-97.

11. Daugrois, J.-H., Dumont, V., Champoiseau, P., Costet, L., Boisne-Noc, R., and Rott, P. 2003. Aerial contamination of sugarcane in Guadeloupe by two strains of Xanthomonas albilineans. Eur. J. Plant Pathol. 109:445-458.

12. Davis, M. J., Rott, P., Baudin, P., and Dean, J. L. 1994. Evaluation of selective media and immunoassays for detection of Xanthomonas albilineans, causal agent of sugarcane leaf scald disease. Plant Dis. 78:78-82.

13. Davis, M. J., Rott, P., Warmuth, C. J., Chatenet, M., and Baudin, P. 1997.
Intraspecific genomic variation within Xanthomonas albilineans, the sugarcane leaf scald pathogen. Phytopathology 87:316-324.

14. Erbs, G., and Newman, M-A. 2012. The role of lipopolysaccharide and peptidoglycan, two glycosylated bacterial microbe-associated molecular patterns (MAMPs), in plant innate immunity. Mol. Plant Pathol. 13:95-104.

15. Gottwald, T. R., Bassanezi, R. B., Amorim, L., and Bergamin-Filho, A 2007. Spatial pattern analysis of citrus canker-infected plantings in Sao Paulo, Brazil, and augmentation of infection elicited by the Asian leafminer. Phytopathology 97:674-683.

16. Gottwald, T. R., Sun, X., Riley, T., Graham, J. H., Ferrandino, F., and Taylor, E. L. 2002. Geo-referenced spatiotemporal analysis of the urban citrus canker epidemic in Florida. Phytopathology 92:361-377.

17. Gottwald, T. R., Timmer, L. W., and McGuire, R. G. 1989. Analysis of disease progress of citrus canker in nurseries in Argentina. Phytopathology 79:1276-1283.

18. Melotto, M., Underwood, W., and He, S. Y. 2008. Role of stomata in plant innate immunity and foliar bacterial diseases. Annu. Rev. Phytopathol. 46:101-122.

19. Milling, A., Babujee, L., and Allen, C. 2011. Ralstonia solanacearum extracellular polysaccharide is a specific elicitor of defense responses in wiltresistant tomato plants. PLoS ONE 6(1):e15853. doi:10.1371/journal.pone. 0015853

20. Milus, E. A., and Mirlohi, A. F. 1993. A test tube assay for estimating populations of Xanthomonas campestris pv. translucens on individual wheat leaves. Phytopathology 83:134-139.

21. Pieretti, I., Royer, M., Barbe, V., Carrere, S., Koebnik, R., Cociancich, S., Couloux, A., Darrasse, A., Gouzy, J., Jacques, M. A., Lauber, E., Manceau, C., Mangenot, S., Poussier, S., Segurens, B., Szurek, B., Verdier, V., Arlat, M., and Rott, P. 2009. The complete genome sequence of Xanthomonas albilineans provides new insights into the reductive genome evolution of the xylem-limited Xanthomonadaceae. BMC Genomics 10:616.

22. Pietrarelli, L., Balestra, G. M., and Varvaro, L. 2006. Effects of simulated rain on Pseudomonas syringae pv. tomato populations on tomato plants. J. Plant Pathol. 88:245-251.

23. Pruvost, O., Gottwald, T. R., and Brocherieux, C. 1999. The effect of irrigation practices on the spatio-temporal increase of Asiatic citrus canker in simulated nursery plots in Reunion Island. Eur. J. Plant Pathol. 105:23-37.

24. Ricaud, C., and Ryan, C. C. 1989. Leaf scald. Pages 39-58 in: Diseases of Sugarcane. Major Diseases. C. Ricaud, B. T. Egan, A. G. Gillaspie, Jr., and C. G. Hughes, eds. Elsevier Publishing Company, Amsterdam.

25. Rott, P., and Davis, M. J. 2000. Leaf scald. Pages 38-44 in: A Guide to Sugarcane Diseases. P. Rott, R. A. Bailey, J. C. Comstock, B. J. Croft, and A. S. Saumtally, eds. La Librairie du Cirad, Montpellier, France.

26. Rott, P., Davis, M. J., and Baudin, P. 1994. Serological variability in Xanthomonas albilineans, causal agent of leaf scald disease of sugarcane. Plant Pathol. 43:344-349.

27. Rott, P., Fleites, L., Marlow, G., Royer, M., and Gabriel, D.W. 2011. Identification of new candidate pathogenicity factors in the xylem-invading pathogen Xanthomonas albilineans by transposon mutagenesis. Mol. PlantMicrobe Interact. 24:594-605.

28. Rott, P., Mohamed, I. S., Klett, P., Soupa, D., de Saint-Albin, A., Feldmann, P., and Letourmy, P. 1997. Resistance to leaf scald disease is associated with limited colonization of sugarcane and wild relatives by Xanthomonas albilineans. Phytopathology 87:1202-1213.

29. Saumtally, S. S., and Dookun, A. 2000. Gumming. Pages 32-37 in: A Guide to Sugarcane Disease. P. Rott, R. A. Bailey, J. C. Comstock, B. J. Croft, and A. S. Saumtally, eds. La Librairie du Cirad, Montpellier.

30. Stall, R. E., Gottwald, T. R., Koizum, M., and Schaad, N. C. 1993. Ecology of plant pathogenic Xanthomonads. Pages 265-299 in: Xanthomonas. J. G. Swings and E. L. Civerolo, eds. Chapman and Hall, London.

31. Wydra, K., Banito, A., and Kpémoua, K. E. 2007. Characterization of resistance of cassava genotypes to bacterial blight by evaluation of leaf and systemic symptoms in relation to yield in different ecozones. Euphytica 155:337-348. 